Environment Conservation Journal 19 (3) 153-159, 2018

ISSN 0972-3099 (Print) 2278-5124 (Online)

Abstracted and Indexed

\title{
Physico chemical characteristics of soil under pine, mixed pine and broad leaved vegetation of Surinsar forest, J\&K
}

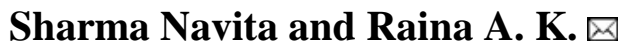

Received: 28.05 .2018

Revised: 28.09.2018

Accepted: 10.11.2018

\begin{abstract}
The present study deals with physico-chemical analysis of soil under pine, mixed pine and broadleaved vegetation of Surinsar forest, Jammu. Soil samples were collected from surface $(0-15 \mathrm{~cm}$ depth) and sub surface $(15-30 \mathrm{~cm}$ depth) layer during rainy, winter and summer season and analysed for moisture content, $\mathrm{pH}$, organic carbon, available nitrogen, potassium and phosphorus. Analysis of the samples revealed that moisture content was higher in surface layer then sub surface layer and decreased from broadleaved to pine vegetation. $\mathrm{pH}$ was acidic in nature and decreased from soil with pine vegetation to broadleaved vegetation during all seasons. Organic carbon, available nitrogen, potassium and phosphorus decreased with increasing soil depth. The concentration of nutrients, except for potassium, was higher during rainy season. The concentration of potassium was found higher during summer season.
\end{abstract}

Key words: Surinsar forest, Moisture content, Organic carbon, Physico-chemical parameters, Soil.

\section{Introduction}

Forest soil is important for the sustenance of vegetation and acts as a source of nutrient, mineral, organic matter in addition to water and air. Physicochemical characteristics of forest soils vary in space and time because of variation in topography, climate, weathering processes, vegetation cover, microbial activities and several other biotic and abiotic factors (Paudal and Sah, 2003). Soil is enriched with basic minerals due to weathering of rocks while organic matter obtained from the decomposition of plants and animal parts enrich it with minerals and nutrients. The fertility of soil depends upon the concentration of $\mathrm{N}, \mathrm{P}, \mathrm{K}$, organic, inorganic materials and water (Shah et al., 2011). The determination of the amount of nutrients in forest soil is of great importance in assessing the soil fertility status and in nutrient cycling studies (Arya, 2014). Several studies related to the nutrient status and physicochemical characteristics of soil in Himalayan forest has been carried out by different workers, (Singh et al., 2009; Sharma et al., 2010; Sheikh and Kumar, 2010; Mishra, 2010; Chandel, 2011; Shameem and Kangroo, 2011; Gairola et al.,

\section{Author's Address}

Deptt of Environmental Sciences, University of Jammu, Jammu-180006

E-mail.: anilkraina@yahoo.com
2012; Joshi et al., 2013; Kaur et al., 2013; Joshi and Negi, 2015) but no such effort has been made in Surinsar forest. Therefore, the present study has been carried out to determine the physico-chemical characteristics of soil under pine, mixed pine and broadleaved vegetation of Surinsar Forest, Jammu. Surinsar forest lies between latitude $32^{\circ} 45^{\prime} 12^{\prime \prime}$ and $32^{\circ} 46^{\prime} 46^{\prime \prime}$ and longitude $75^{\circ} 01^{\prime} 44^{\prime \prime}$ and $75^{\circ} 03^{\prime} 42^{\prime \prime}$ $\mathrm{E}$ and is about $40 \mathrm{kms}$ to the north-east of Jammu city. The area has sub-tropical monsoon climate, the average rainfall is around $1500 \mathrm{~mm}$. There is great extremes of temperature with June recorded as hottest and January as coldest month with average maximum and minimum temperature of $39^{\circ} \mathrm{C}$ and $6.8^{\circ} \mathrm{C}$, respectively. The area exhibit different forest types consisting of northern dry mixed deciduous forest, Himalayan subtropical scrub and Himalayan subtropical Pine forest having Pinus roxburghii, Mallotus phillipensis, Ficus religiosa, Dalbergia sissoo, and Acacia as prominent species.

\section{Material and Methods}

Soil samples were collected from three sites Site I

(Pine), Site II (Mixed Pine) and Site III (broad leaved vegetation). Soil sampling was done from 2013 to 2015 during rainy, winter and summer 


\section{Sharma and Raina}

season from surface $(0-15 \mathrm{~cm}$ depth $)$ and sub surface $(15-30 \mathrm{~cm}$ depth) layers with the help of augur in polythene bags and were sealed and labelled properly. Soil moisture was determined gravimetrically by taking weight of fresh soil and dry soil (oven-drying at $105^{\circ} \mathrm{C}$ for about $24 \mathrm{~h}$ ), soil $\mathrm{pH}$ was determined in 1: 2 water suspensions, Soil organic carbon (OC) was determined by Walkley and Black (1934) method. Available nitrogen (N) was measured by the alkaline permanganate method (Subbiah and Asija, 1956), available phosphorus (P) was analyzed by spectrophotometric method (Jackson, 1958) at 660mu, available potassium $(\mathrm{K})$ by using the flame photometer (Jackson, 1958).

\section{Results and Discussion}

The variation in the physico-chemical properties of soil under pine, mixed Pine and broadleaved vegetation across different soil depth and seasons for the two years (2013-14 and 2014-2015) has been presented in tables 1 and 2 while the average of different physico-chemical parameters for the two years has been given in table 3 .

Soil moisture content influences the physical, chemical, biological properties and nutrient uptake capacity of soil. It was higher in broadleaved vegetation as compare to pine, however, it increases with increasing soil depth at all the sites. The maximum average value was recorded during rainy season from site III i.e $15.34 \pm 2.84 \%$ for surface layer and $10.27 \pm 2.32 \%$ from site II for sub surface layer. The average moisture content ranges from $3.76 \%$ to $13.47 \%$ at all the sites and depth and during different seasons. A fixed seasonal trend in soil moisture has been reported by Joshi et al. (2013) with maximum in rainy season $(20.55 \% \pm$ 3.90) (Aug) and minimum in summer season (8.84\% \pm 3.96) (May). Jina et al. (2011) has also reported soil moisture to range between $6.56 \pm 0.16$ and 18.07 \pm 0.44 in degraded and non - degraded forest of Lamgarha Block in district Almora, respectively. However, higher soil moisture variation (21\% to $65 \%$ ) has been reported by Joshi et al. (2002) in the buffer zone of Nanda Devi Biosphere Reserve in western Himalaya. Soil pH determines the availability of nutrients by affecting the solubility of minerals and nutrients and also the microbial growth in the soil. Soils become acidic due to leaching of ions and decomposition of organic matter. In the present study, soil $\mathrm{pH}$ was found to be acidic in nature in surface layer where its average value ranges from 5.57 to 6.11 while less acidic nature has been recorded in sub surface layer where average $\mathrm{pH}$ value ranges from 5.73 to 6.39. The acidic nature of the soil has also been reported by Jina et al. (2011); Joshi et al. (2013) and Nazir and Samweel (2013) in different forests.

Organic carbon in soil is the carboneous part of the forest litter which has been freed by microbes during the process of decomposition of forest litter (Arya, 2014). It plays an important role in improving soil quality and forest production. In the present study, higher concentration of organic carbon, available nitrogen, potassium, phosphorus has been recorded in surface layer of soil than sub surface layer at all the sites during all the three season i.e rainy, winter and summer season and the concentration of these parameters increases in soil covered with Pine vegetation to soil covered with broad leaved vegetation. The higher value of these nutrients from broad leaved forest has also been reported by Kaur et al. (2013). In the present investigation, average concentrations of soil organic carbon ranges from $0.09 \%$ to $0.59 \%, 0.09 \%$ to $0.60 \%, 0.11 \%$ to $0.88 \%$ at site I, site II and site III, respectively. However, higher concentration of organic carbon have been reported by Sheikh and Kumar (2010) and Mishra (2010).

Nitrogen, potassium, phosphorus are essential and inevitable for the growth of forest vegetation. Average concentrations of available nitrogen, in the present study area, ranges from $0.008 \%$ to $0.014 \%$, $0.010 \%$ to $0.016,0.011 \%$ to $0.017 \%$ at site I, site II and site III, respectively and was found higher during rainy season as compared to winter and summer season. It was close to the findings of Joshi and Negi (2015) while Semwal et al., (2009) reported higher values of nitrogen in pine forest. Available phosphorus has also been found higher during rainy season and its average concentration for site I, site II and site III ranged from 11.30 $\mathrm{kg} / \mathrm{h}$ a to $22.60 \mathrm{~kg} / \mathrm{ha}, 12.73 \mathrm{~kg} / \mathrm{ha}$ to $21.88 \mathrm{~kg} / \mathrm{ha}$ and $14.58 \mathrm{~kg} / \mathrm{ha}$ to $25.74 \mathrm{~kg} / \mathrm{ha}$, respectively. It was comparable to the values reported by Bhandari et al. (2000) i.e. 14.40 to $21.60 \mathrm{~kg} / \mathrm{ha}$ but higher than reported by Kumar et al. (2004) i.e 9.3 to $18.2 \mathrm{~kg}$ /ha. Comparatively higher concentrations of available potassium in the present study area has 
Physico chemical characteristics of soil under pine, mixed pine and broad leaved vegetation

Table 1: Physico-chemical characteristics of soil during rainy, winter and summer seasons of 2013-2014.

\begin{tabular}{|c|c|c|c|c|c|c|c|c|c|c|}
\hline \multirow{2}{*}{$\begin{array}{l}\text { Soil } \\
\text { characteristic }\end{array}$} & & \multicolumn{3}{|l|}{ Rainy season } & \multicolumn{3}{|l|}{ Winter season } & \multicolumn{3}{|c|}{ Summer season } \\
\hline & $\begin{array}{l}\begin{array}{l}\text { Soil } \\
\text { depth } \\
(\mathrm{cm})\end{array} \\
\end{array}$ & $\begin{array}{l}\text { Pine } \\
\text { (Site I) }\end{array}$ & $\begin{array}{l}\text { Mixed pine } \\
\text { (Site II) }\end{array}$ & $\begin{array}{l}\text { Broadleaved } \\
\text { vegetation } \\
\text { (Site III) } \\
\end{array}$ & $\begin{array}{l}\text { Pine } \\
\text { (Site I) }\end{array}$ & $\begin{array}{l}\text { Mixed pine } \\
\text { (Site II) }\end{array}$ & $\begin{array}{l}\text { Broadleaved } \\
\text { vegetation } \\
\text { (Site III) } \\
\end{array}$ & $\begin{array}{l}\text { Pine } \\
\text { (Site I) }\end{array}$ & $\begin{array}{l}\text { Mixed pine } \\
\text { (Site II) }\end{array}$ & $\begin{array}{l}\text { Broadleaved } \\
\text { vegetation } \\
\text { (Site III) } \\
\end{array}$ \\
\hline \multirow{2}{*}{$\begin{array}{l}\text { Moisture } \\
\text { content } \\
(\%)\end{array}$} & $0-15$ & $11.83 \pm 1.34$ & $13.74 \pm 4.83$ & $15.74 \pm 2.22$ & $7.59 \pm 1.35$ & $8.49 \pm 1.53$ & $11.08 \pm 0.69$ & $3.72 \pm 0.99$ & $7.27 \pm 3.61$ & $6.77 \pm 2.64$ \\
\hline & $15-30$ & $10.28 \pm 2.91$ & $11.63 \pm 2.68$ & $8.79 \pm 0.55$ & $7.07 \pm 2.00$ & $7.43 \pm 1.35$ & $8.64 \pm 2.95$ & $4.13 \pm 1.60$ & $5.55 \pm 2.34$ & $5.44 \pm 3.46$ \\
\hline \multirow[t]{2}{*}{ pH } & $0-15$ & $5.86 \pm 0.25$ & $5.34 \pm 0.10$ & $5.54 \pm 0.24$ & $5.85 \pm 0.08$ & $5.67 \pm 0.18$ & $5.60 \pm 0.14$ & $6.33 \pm 0.32$ & $5.98 \pm 0.14$ & $5.67 \pm 0.05$ \\
\hline & $15-30$ & $6.15 \pm 0.19$ & $5.69 \pm 0.18$ & $5.74 \pm 0.23$ & $6.15 \pm 0.18$ & $5.73 \pm 0.22$ & $5.86 \pm 0.18$ & $6.54 \pm 0.37$ & $6.14 \pm 0.31$ & $6.05 \pm 0.12$ \\
\hline \multirow{2}{*}{$\begin{array}{l}\text { Organic } \\
\text { carbon } \\
(\%)\end{array}$} & $0-15$ & $0.65 \pm 0.08$ & $0.70 \pm 0.08$ & $1.05 \pm 0.07$ & $0.25 \pm 0.08$ & $0.36 \pm 0.04$ & $0.76 \pm 0.09$ & $0.22 \pm 0.019$ & $0.34 \pm 0.03$ & $0.35 \pm 0.10$ \\
\hline & $15-30$ & $0.34 \pm 0.08$ & $0.35 \pm 0.03$ & $0.44 \pm 0.08$ & $0.15 \pm 0.04$ & $0.20 \pm 0.14$ & $0.26 \pm 0.05$ & $0.08 \pm 0.03$ & $0.07 \pm 0.03$ & $0.21 \pm 0.02$ \\
\hline \multirow{2}{*}{$\begin{array}{l}\text { Nitrogen } \\
(\%)\end{array}$} & $0-15$ & $0.015 \pm 0.1$ & $0.016 \pm 0.001$ & $0.018 \pm 0.001$ & $0.011 \pm 0.0030$ & $0.013 \pm 0.0010$ & $0.017 \pm 0.0010$ & $0.010 \pm 0.0018$ & $0.013 \pm 0.0004$ & $0.015 \pm 0.0009$ \\
\hline & $15-30$ & $0.012 \pm 0.002$ & $0.012 \pm 0.002$ & $0.016 \pm 0.001$ & $0.008 \pm 0.0020$ & $0.010 \pm 0.0017$ & $0.012 \pm 0.0006$ & $0.008 \pm 0.0011$ & $0.010 \pm 0.0008$ & $0.012 \pm 0.0007$ \\
\hline \multirow{2}{*}{$\begin{array}{l}\text { Phosphorus } \\
\text { (kg/ha) }\end{array}$} & $0-15$ & $21.74 \pm 1.79$ & $23.45 \pm 1.31$ & $25.74 \pm 2.97$ & $20.31 \pm 2.15$ & $22.60 \pm 5.02$ & $24.88 \pm 2.27$ & $17.16 \pm 1.78$ & $18.30 \pm 4.05$ & $20.02 \pm 2.15$ \\
\hline & $15-30$ & $17.45 \pm 1.78$ & $18.31 \pm 3.01$ & $18.87 \pm 3.43$ & $15.16 \pm 3.47$ & $16.31 \pm 2.27$ & $16.30 \pm 3.93$ & $12.30 \pm 1.31$ & $13.15 \pm 1.71$ & $13.44 \pm 4.85$ \\
\hline \multirow{2}{*}{$\begin{array}{l}\text { Potassium } \\
\text { (kg/ha) }\end{array}$} & $0-15$ & $79.59 \pm 12.47$ & $88.90 \pm 14.88$ & $117.03 \pm 15.27$ & $70.64 \pm 13.81$ & $93.39 \pm 12.47$ & $113.29 \pm 2.12$ & $83.39 \pm 10.10$ & $92.10 \pm 18.51$ & $122.92 \pm 4.74$ \\
\hline & $15-30$ & $55.00 \pm 12.24$ & $72.43 \pm 22.45$ & $91.45 \pm 13.86$ & $54.77 \pm 11.46$ & $68.99 \pm 18.95$ & $79.47 \pm 6.79$ & $59.07 \pm 8.37$ & $74.40 \pm 18.48$ & $96.74 \pm 10.28$ \\
\hline
\end{tabular}




\section{Sharma and Raina}

Table 2: Physico-chemical characteristics of soil during rainy, winter and summer seasons of 2014-2015.

\begin{tabular}{|c|c|c|c|c|c|c|c|c|c|c|}
\hline \multirow{2}{*}{$\begin{array}{l}\text { Soil } \\
\text { characteristic }\end{array}$} & & \multicolumn{3}{|l|}{ Rainy season } & \multicolumn{3}{|l|}{ Winter season } & \multicolumn{3}{|c|}{ Summer season } \\
\hline & $\begin{array}{l}\begin{array}{l}\text { Soil } \\
\text { depth } \\
(\mathrm{cm})\end{array} \\
\end{array}$ & $\begin{array}{l}\text { Pine } \\
\text { (Site I) }\end{array}$ & $\begin{array}{l}\text { Mixed pine } \\
\text { (Site II) }\end{array}$ & $\begin{array}{l}\text { Broadleaved } \\
\text { vegetation } \\
\text { (Site III) } \\
\end{array}$ & $\begin{array}{l}\text { Pine } \\
\text { (Site I) }\end{array}$ & $\begin{array}{l}\text { Mixed pine } \\
\text { (Site II) }\end{array}$ & $\begin{array}{l}\text { Broadleaved } \\
\text { vegetation } \\
\text { (Site III) }\end{array}$ & $\begin{array}{l}\text { Pine } \\
\text { (Site I) }\end{array}$ & $\begin{array}{l}\text { Mixed pine } \\
\text { (Site II) }\end{array}$ & $\begin{array}{l}\text { Broadleaved } \\
\text { vegetation } \\
\text { (Site III) }\end{array}$ \\
\hline \multirow{2}{*}{$\begin{array}{l}\text { Moisture } \\
\text { content }(\%)\end{array}$} & $0-15$ & $12.83 \pm 5.67$ & $13.20 \pm 2.51$ & $14.93 \pm 4.01$ & $9.13 \pm 2.37$ & $8.71 \pm 1.65$ & $8.95 \pm 1.56$ & $4.98 \pm 1.41$ & $7.00 \pm 1.48$ & $7.38 \pm 0.93$ \\
\hline & $15-30$ & $7.93 \pm 0.27$ & $8.90 \pm 2.04$ & $11.18 \pm 2.75$ & $6.03 \pm 1.93$ & $5.56 \pm 0.84$ & $6.24 \pm 1.16$ & $3.40 \pm 1.83$ & $5.20 \pm 1.12$ & $4.62 \pm 1.99$ \\
\hline \multirow[t]{2}{*}{ pH } & $0-15$ & $5.93 \pm 0.09$ & $5.65 \pm 0.09$ & $5.54 \pm 0.12$ & $6.29 \pm 0.26$ & $5.92 \pm 0.21$ & $5.67 \pm 0.05$ & $6.36 \pm 0.15$ & $5.83 \pm 0.39$ & $5.76 \pm 0.24$ \\
\hline & $15-30$ & $6.30 \pm 0.10$ & $5.73 \pm 0.19$ & $5.82 \pm 0.19$ & $6.56 \pm 0.34$ & $6.15 \pm 0.27$ & $5.77 \pm 0.19$ & $6.62 \pm 0.03$ & $6.25 \pm 0.40$ & $6.04 \pm 0.31$ \\
\hline \multirow{2}{*}{$\begin{array}{l}\text { Organic } \\
\text { carbon }(\%)\end{array}$} & $0-15$ & $0.48 \pm 0.11$ & $0.51 \pm 0.077$ & $0.71 \pm 0.12$ & $0.46 \pm 0.05$ & $0.37 \pm 0.07$ & $0.49 \pm 0.034$ & $0.18 \pm 0.07$ & $0.41 \pm 0.14$ & $0.35 \pm 0.05$ \\
\hline & $15-30$ & $0.21 \pm 0.13$ & $0.28 \pm 0.06$ & $0.38 \pm 0.03$ & $0.14 \pm 0.04$ & $0.08 \pm 0.059$ & $0.24 \pm 0.025$ & $0.09 \pm 0.06$ & $0.19 \pm 0.12$ & $0.11 \pm 0.08$ \\
\hline \multirow[t]{2}{*}{ Nitrogen (\%) } & $0-15$ & $0.014 \pm 0.0007$ & $0.015 \pm 0.0011$ & $0.016 \pm 0.0006$ & $0.012 \pm 0.0007$ & $0.013 \pm 0.0012$ & $0.014 \pm 0.0012$ & $0.010 \pm 0.001$ & $0.012 \pm 0.001$ & $0.015 \pm 0.001$ \\
\hline & $15-30$ & $0.010 \pm 0.0019$ & $0.011 \pm 0.0014$ & $0.012 \pm 0.0010$ & $0.008 \pm 0.0006$ & $0.010 \pm 0.0008$ & $0.011 \pm 0.0003$ & $0.007 \pm 0.001$ & $0.010 \pm 0.001$ & $0.010 \pm 0.002$ \\
\hline \multirow{2}{*}{$\begin{array}{l}\text { Potassium } \\
\text { (kg/ha) }\end{array}$} & $0-15$ & $18.59 \pm 1.79$ & $20.31 \pm 2.62$ & $23.17 \pm 2.27$ & $18.88 \pm 2.27$ & $20.31 \pm 4.40$ & $20.60 \pm 2.57$ & $16.59 \pm 3.25$ & $18.02 \pm 3.93$ & $20.59 \pm 3.90$ \\
\hline & $15-30$ & $15.44 \pm 1.48$ & $14.87 \pm 2.61$ & $18.87 \pm 3.43$ & $15.45 \pm 1.71$ & $13.44 \pm 2.15$ & $14.30 \pm 0.50$ & $10.29 \pm 2.27$ & $12.30 \pm 1.79$ & $15.73 \pm 2.16$ \\
\hline \multirow{2}{*}{$\begin{array}{l}\text { Phosphorus } \\
\text { (kg/ha) }\end{array}$} & $0-15$ & $69.60 \pm 4.73$ & $76.12 \pm 13.85$ & $108.80 \pm 4.50$ & $76.33 \pm 6.52$ & $99.68 \pm 11.87$ & $114.04 \pm 14.57$ & $85.41 \pm 8.23$ & $99.97 \pm 16.37$ & $122.78 \pm 16.70$ \\
\hline & $15-30$ & $48.49 \pm 3.23$ & $55.11 \pm 10.92$ & $75.28 \pm 1.81$ & $55.67 \pm 8.23$ & $70.49 \pm 13.61$ & $89.35 \pm 17.25$ & $63.75 \pm 4.80$ & $79.62 \pm 12.71$ & $99.14 \pm 14.69$ \\
\hline
\end{tabular}


Physico chemical characteristics of soil under pine, mixed pine and broad leaved vegetation

Table 3: Average of physico-chemical characteristics of soil during rainy, winter and summer seasons of two years

\begin{tabular}{|c|c|c|c|c|c|c|c|c|c|c|}
\hline \multirow{2}{*}{$\begin{array}{l}\text { Soil } \\
\text { characteristic }\end{array}$} & & \multicolumn{3}{|l|}{ Rainy season } & \multicolumn{3}{|l|}{ Winter season } & \multicolumn{3}{|c|}{ Summer season } \\
\hline & $\begin{array}{l}\begin{array}{l}\text { Soil } \\
\text { depth }\end{array} \\
(\mathrm{cm})\end{array}$ & $\begin{array}{l}\text { Pine } \\
\text { (Site I) }\end{array}$ & $\begin{array}{l}\text { Mixed pine } \\
\text { (Site II) }\end{array}$ & $\begin{array}{l}\text { Broad leaved } \\
\text { vegetation } \\
\text { (Site III) } \\
\end{array}$ & $\begin{array}{l}\text { Pine } \\
\text { (Site I) }\end{array}$ & $\begin{array}{l}\text { Mixed pine } \\
\text { (Site II) }\end{array}$ & $\begin{array}{l}\text { Broad leaved } \\
\text { vegetation } \\
\text { (Site III) }\end{array}$ & $\begin{array}{l}\text { Pine } \\
\text { (Site I) }\end{array}$ & $\begin{array}{l}\text { Mixed pine } \\
\text { (Site II) }\end{array}$ & $\begin{array}{l}\text { Broad leaved } \\
\text { vegetation } \\
\text { (Site III) }\end{array}$ \\
\hline \multirow{2}{*}{$\begin{array}{l}\text { Moisture } \\
\text { content }(\%)\end{array}$} & $0-15$ & $12.33 \pm 3.50$ & $13.47 \pm 1.69$ & $15.34 \pm 2.84$ & $8.36 \pm 1.25$ & $8.60 \pm 0.59$ & $10.02 \pm 1.00$ & $4.35 \pm 1.20$ & $7.14 \pm 2.33$ & $7.07 \pm 1.78$ \\
\hline & $15-30$ & $9.11 \pm 1.51$ & $10.27 \pm 2.32$ & $9.99 \pm 1.10$ & $6.55 \pm 0.77$ & $6.50 \pm 0.75$ & $7.46 \pm 0.84$ & $3.76 \pm 1.65$ & $5.37 \pm 1.73$ & $5.04 \pm 2.72$ \\
\hline \multirow[t]{2}{*}{ pH } & $0-15$ & $5.89 \pm 0.06$ & $5.66 \pm 0.14$ & $5.57 \pm 0.042$ & $6.10 \pm 0.21$ & $5.73 \pm 0.19$ & $5.63 \pm 0.05$ & $6.11 \pm 0.35$ & $5.59 \pm 0.35$ & $5.65 \pm 0.16$ \\
\hline & $15-30$ & $6.23 \pm 0.11$ & $5.73 \pm 0.00$ & $5.84 \pm 0.28$ & $6.39 \pm 0.16$ & $5.95 \pm 0.21$ & $5.88 \pm 0.04$ & $6.39 \pm 0.33$ & $5.97 \pm 0.40$ & $5.89 \pm 0.21$ \\
\hline \multirow{2}{*}{$\begin{array}{l}\text { Organic } \\
\text { carbon }(\%)\end{array}$} & $0-15$ & $0.59 \pm 0.095$ & $0.60 \pm 0.13$ & $0.88 \pm 0.032$ & $0.26 \pm 0.018$ & $0.28 \pm 0.04$ & $0.47 \pm 0.04$ & $0.13 \pm 0.086$ & $0.25 \pm 0.051$ & $0.23 \pm 0.045$ \\
\hline & $15-30$ & $0.27 \pm 0.10$ & $0.32 \pm 0.05$ & $0.41 \pm 0.031$ & $0.10 \pm 0.04$ & $0.11 \pm 0.08$ & $0.19 \pm 0.02$ & $0.09 \pm 0.027$ & $0.09 \pm 0.028$ & $0.11 \pm 0.033$ \\
\hline \multirow[t]{2}{*}{ Nitrogen (\%) } & $0-15$ & $0.014 \pm 0.0007$ & $0.016 \pm 0.0007$ & $0.017 \pm 0.0007$ & $0.011 \pm 0.0015$ & $0.013 \pm 0.0010$ & $0.016 \pm 0.0003$ & $0.010 \pm 0.0013$ & $0.013 \pm 0.0003$ & $0.015 \pm 0.0005$ \\
\hline & $15-30$ & $0.011 \pm 0.0009$ & $0.012 \pm 0.0021$ & $0.013 \pm 0.0004$ & $0.008 \pm 0.0008$ & $0.010 \pm 0.0008$ & $0.012 \pm 0.0004$ & $0.008 \pm 0.0011$ & $0.010 \pm 0.0008$ & $0.011 \pm 0.0015$ \\
\hline \multirow{2}{*}{$\begin{array}{l}\text { Phosphorus } \\
\text { (kg/ha) }\end{array}$} & $0-15$ & $20.17 \pm 2.27$ & $21.88 \pm 2.22$ & $24.46 \pm 1.82$ & $22.60 \pm 3.89$ & $20.74 \pm 1.79$ & $25.74 \pm 3.00$ & $16.88 \pm 1.73$ & $18.16 \pm 1.93$ & $20.31 \pm 3.65$ \\
\hline & $15-30$ & $16.45 \pm 1.42$ & $16.59 \pm 2.43$ & $18.87 \pm 0.00$ & $16.73 \pm 5.96$ & $15.73 \pm 1.38$ & $17.16 \pm 0.42$ & $11.30 \pm 1.79$ & $12.73 \pm 1.37$ & $14.58 \pm 2.15$ \\
\hline \multirow{2}{*}{$\begin{array}{l}\text { Potassium } \\
\text { (kg/ha) }\end{array}$} & $0-15$ & $74.59 \pm 8.52$ & $82.51 \pm 14.29$ & $112.92 \pm 6.41$ & $73.48 \pm 9.66$ & $96.54 \pm 12.07$ & $113.67 \pm 8.37$ & $84.40 \pm 8.98$ & $96.09 \pm 17.41$ & $122.85 \pm 10.64$ \\
\hline & $15-30$ & $51.74 \pm 7.66$ & $63.77 \pm 16.53$ & $83.36 \pm 7.79$ & $55.23 \pm 9.34$ & $69.74 \pm 16.24$ & $84.41 \pm 12.01$ & $61.42 \pm 6.66$ & $77.01 \pm 15.59$ & $97.94 \pm 12.23$ \\
\hline
\end{tabular}




\section{Sharma and Raina}

been recorded during summer season as compared to rainy and winter season at all the sites and it ranges from $51.74 \mathrm{~kg} / \mathrm{ha}$ to $112.92 \mathrm{~kg} / \mathrm{ha}$ during rainy season, $55.23 \mathrm{~kg} / \mathrm{ha}$ to $113.67 \mathrm{~kg} / \mathrm{ha}$ during winter season and $61.42 \mathrm{~kg} / \mathrm{ha}$ to $122.85 \mathrm{~kg} / \mathrm{ha}$ during summer season This may be due to leaching of potassium during rainy season. Sheikh and Kumar (2010) and Jina et al. (2011) have also reported higher values of potassium in oak and pine forest

\section{Conclusion}

Higher concentration of nutrients has been recorded in broad leaved as compared to pine and mixed pine forest vegetation. Also, higher concentration of all the nutrients has been recorded during rainy season except for potassium, concentration of which was found higher during summer season. Higher concentration of these nutrients during rainy season indicates that high moisture content in soil favour higher decomposition of litter and release of nutrients in soil. Surface layer of soil possessed higher moisture content and nutrients as compare to sub surface layer. Acidity of soil decreases with depth. It has been found that the physio-chemical characteristics of soil are linked with vegetation type and season.

\section{References}

Arya, K. M., 2014. Assessment of physico-chemical properties of soil along altitudinal gradients in a protected forest in the Kumau Himalayas, India. Nature and Science, 12(2): 32-37.

Bhandari, B. S., Mehta J. P. and Tiwari S. C., 2000. Dominance and diversity relations of woody vegetation structure along an altitudinal gradient in a montane fores of Garhwal Himalaya. Journal of Tropical Forest Science, 12(1): 49-61.

Chandel B., 2011. Physical and chemical characteristics of soil in Ramnagar wildlife sanctuary. MPhil Thesis. Department of Environmental Sciences, University of Jammu.

Gairola, S., Sharma, C. M., Ghildiyal, S. K. and Suyal, S., 2012. Chemical properties of soil in relation to forest composition in moist temperate valley slopes at Garhwal Himalaya India. Environmentalist, 32(4): 512-523

Jackson, M. L., 1958. Soil chemical analysis. Prentice-Hall Inc., Englewood Cliffs, New Jersey.
Jina, B. S., Bohra, C. S., Lodhiyal, L. S. and Sah, P., 2011. Soil characteristics in oak and pine forests of Indian Central Himalaya. International Scientific Research, 3(1): 19-22.

Joshi, G. and Negi, G. C. S., 2015. Physico-chemical properties along soil profiles of two dominant forest types in Western Himalaya. Current Science, 109(4): 798-801.

Joshi, P. C., Badoni, V. and Arya, A., 2002. Some geoecological aspects of Pindar valley, district Bageshwar (Uttaranchal). Indian Himalayan Journal of Environmental Zoology, 16 (2): 271- 279.

Joshi, P.C., Pandey P. and Kaushal, B. R., 2013. Analysis of some physico chemical parameters of soil from a protected forest in Uttarakhand. Nature and Science, 11(1): 136-140.

Kaur, R., Sharma, M. and Puri, S., 2013. Comparisoion of nutrient distribution in monoculture and polyculture landuse system of sub temperate mid hills of Himachal Pradesh. Global Journal of Biology, Agriculture and Health Sciences, 2(2):42-45.

Kumar, M., Sharma, C. M. and Rajawar, G. S., 2004. Physicochemical properties of forest soil along altitudinal gradient in Gharwal Himalaya. Journal of Hill Research, 17(2): 60-64.

Mishra, B. P., 2010. Vegetation composition and soil nutrient status from polyculture to monoculture. African Journal Of Environmental Sciences and Technology, 5 (5):363366.

Nazir, T and Samweel, N., 2013. Soil nutrient status under pine and oak forests in temprate valley slopes of Gharwal Himalaya, India. International Journal of Current Research 12(15): 4309-4315.

Paudal. S. and Sah, J. P., 2003. Physico-chemical charctercterstics of soil in tropical Sal (Shorea robusta) forest in eastern Nepal. Himalayan journal of sciences 1(2):107-110.

Shah, M., Shilpkar, P., Shah, A., Sadara, I. A. and Vaghela, A., 2011. Physico-chemical charcterstics of soil of Dahegam Taluka, Gujarat. Journal of Advances in developmental Research, 2(1): 50-53.

Shameem, S.A and Kangroo I. N., 2011. Comparative assessment of edapic features and phytodiversity in lower Dachigam national park, Kashmir Himalaya India. African Journal of Environmental Sciences and Technology, 5(11): 972-984.

Sharma, C. M., Baduni, N. P., Gairola, S., Ghildiyal, S. K. and Suyal, S., 2010. Effect of slope aspects on forest composition, community structures and soil properties in natural temperate forest of Garhwal Himalaya. Journal of Forestery Research, 21(3):331-337. 
Semwal, D. P., Uniyal, P. L., Bahugun, Y. M., and Bhat, A. B., 2009. Soil nutrient storage under different forest type in part of central Himalayas, India. Annels of Forestery, 17(1): 43-52.

Singh, H., Kumar, M. and Sheikh, M. A., 2009. Distribution pattern of oak and pine along altitudinal gradients in Gharwal Himalaya. Nature and Science, 7(11): 81-85.

Sheikh, A. M. and Kumar, M., 2010. Nutrient status and economic analysis of soils in oak and pine forests in
Garhwal Himalaya. Journal of American Science 6(2)117122.

Subbiah, B. V. and Asija, L. G., 1956. A rapid procedure for the estimation of available nitrogen in soils. Current science, 25: 259-260.

Walkley, A. and Black, A.I. 1934. An examination of the Detjareff method for determinimg soil organic matter and a proposed modification to the chronic and titrarion method. Soil science, 37: 29-38. 